\title{
2.1 Herausgebereingriffe
}

Die Vorlage für den edierten Text D ist der Privatdruck PD, dessen orthographische Eigenheiten bewahrt werden (vgl. Vorbemerkung, S. 24). Nur bei offenkundigen Satzund Druckfehlern wurde gegenüber der Textgestalt von PD eingegriffen:

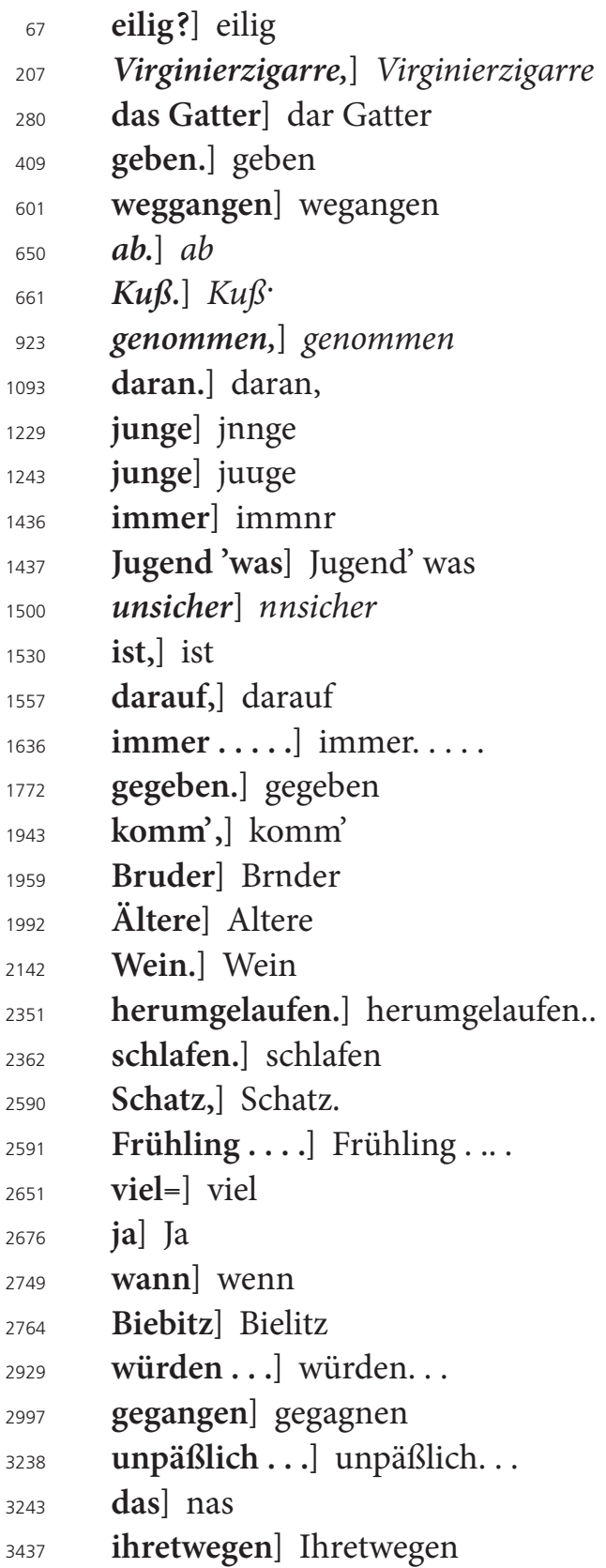




$\begin{array}{ll}3516 & \text { bitten] bittten } \\ 3538 & \text { Frauenzimmern ... .] Frauenzimmern. . . } \\ 3561 & \text { nach] na } \\ 3700 & \text { sitzen,] sitzen } \\ 3741 & \text { ähnlich] ählich } \\ 3766 & \text { hervor).] hervor. } \\ 3857 & \text { wieder.] wieder } \\ 3977 & \text { hab ....] hab. ... }\end{array}$

